RESEARCH Note

\title{
Observations on the early development of the kelpfish Myxodes viridis (Clinidae) with the first description of their spawning habitat in subtidal kelp forests (Lessonia trabeculata)
}

Observaciones del desarrollo temprano de la doncellita, Myxodes viridis (Clinidae), y la primera descripción de su hábitat de desove en bosques de macroalgas pardas submareales (Lessonia trabeculata)

\section{Catalina S. Ruz ${ }^{1 *}$, Vladimir Garmendia ${ }^{1}$, Rodrigo Muñoz-Cordovez ${ }^{1}$, Evie Wieters ${ }^{2}$ and Alejandro Pérez-Matus ${ }^{1}$}

\footnotetext{
${ }^{1}$ Subtidal Ecology Laboratory, Estación Costera de Investigaciones Marinas, Facultad de Ciencias Biológicas, Departamento de Ecología, Pontificia Universidad Católica de Chile, Casilla 114-D, Santiago, Chile

${ }^{2}$ Estación Costera de Investigaciones Marinas, Facultad de Ciencias Biológicas, Pontificia Universidad Católica de Chile, Casilla 114-D, Santiago, Chile

*Corresponding author: sallen.ruz@gmail.com
}

\begin{abstract}
The spawning sites, embryonic development, and initial larval stages were described for the Chilean kelpfish, Myxodes viridis. Six different egg clutches were found attached by an elastic filament to the fronds of the subtidal kelp, Lessonia trabeculata, at shallow depths $(0-7 \mathrm{~m})$. All egg clutches were cared for by one large $(>15 \mathrm{~cm} \mathrm{TL})$ male, and egg color varied depending on the developmental stage. Embryonic development until hatching was categorized into 7 stages, which were completed within about 18 days in the laboratory. Recently hatched larvae presented fully pigmented eyes, a well-developed mouth with major shape changes in the head during the first week suggesting their ability to feed on plankton early in their larval development.
\end{abstract}

Key words: Kelpfish, spawning site, embryonic development, hatching, larvae

\section{INTRODUCTION}

Kelpfishes are a subgroup of species in the Clinidae family. Generally small in size, they live among the fronds of large brown macroalgae, turf algae, and seagrass in rocky substrates (Stepien 1990, 1992). Clinids belong to the monophyletic group Blennoidei, which share similar aspects of their reproductive biology and mating processes (Hastings \& Petersen 2010). In general, most of these fishes use external fertilization, where females choose a spawning site and lay their eggs, then males fertilize and guard them (Hastings \& Petersen 2010). The egg development success is determined, at least in part, by the oxygenation and temperature requirements suitable for embryonic development (Miller \& Kendall 2009). Thus, site features (i.e., water flow, substrate type, depth, refuge availability, Helfman et al. 2009) and the male parental care abilities to guard and aerate the nest are essential aspects that parents must fulfill (Gross 2005, Navarrete-Fernández et al. 2014).
In the southeastern Pacific, kelpfishes of the genus Myxodes are distributed from Bahía Independencia, Perú (146'S) to southern Chile (5057.9'S) (Navarro \& Pequeño 1979, Stepien 1990) and include Myxodes viridis (Valenciennes, 1836), Myxodes cristatus (Valenciennes, 1836) and Myxodes ornatus (Stephens \& Springer, 1973). Specific information about larval development and feeding habits have been reported only for $M$. viridis, whose pelagic larvae shift from omnivorous to strictly carnivorous, coinciding with morphological shape changes during development (Muñoz \& Ojeda 1998, Ochoa-Muñoz et al. 2013, Zavala-Muñoz et al. 2016). Benthic post-larval recruits and adults can be found in rocky intertidal habitats (Mansur et al. 2014), where they are considered important microcarnivores that feed on a wide variety of copepods, amphipods, isopods and snails (Stepien 1990, Quijada \& Cáceres 2000). Juveniles and adults are also known to use Lessonia trabeculata and Macrocystis pyrifera kelp forests 
in the shallow subtidal, where they have been particularly overlooked, probably due to their cryptic nature (Stepien 1990, Pérez-Matus et al. 2007, Reyes \& Hüne 2012). However, no information about reproductive behavior and early life history stages (i.e., eggs, embryos, settling larvae) of $M$. viridis have been described, as well as embryological development traits or spawning habitats.

During early developmental stages, shape changes are critical to face the pelagic life and posterior recruitment success (Fuiman \& Higgs 1997, Frederich et al. 2008). Morphological studies may provide useful information about the ecological strategies on early developmental stages in fishes (Frederich et al. 2008, Zavala-Muñoz et al. 2016, Bernal-Durán \& Landaeta 2017, Landaeta et al. 2019,
Muñoz-Cordovez et al. 2019) and geometric morphometrics has been a useful tool to capture shape changes dealing with the scaling, position, and orientation of the shape through the ontogeny (Toro-Ibacache et al. 2010, Klingenberg 2011).

In the present paper, observations of $M$. viridis egg clutches found on L. trabeculata sporophytes are presented (Fig. 1). This work aims to describe the spatial location of the spawning site, the timing of embryonic developmental stages, and the main shape changes of recently hatched larvae. Although the kelp forests of central Chile have long been the focus of field studies by fish ecologists, this is the first time spawning of $M$. viridis is described, contributing novel information for the species and the association between the kelpfish and kelp.
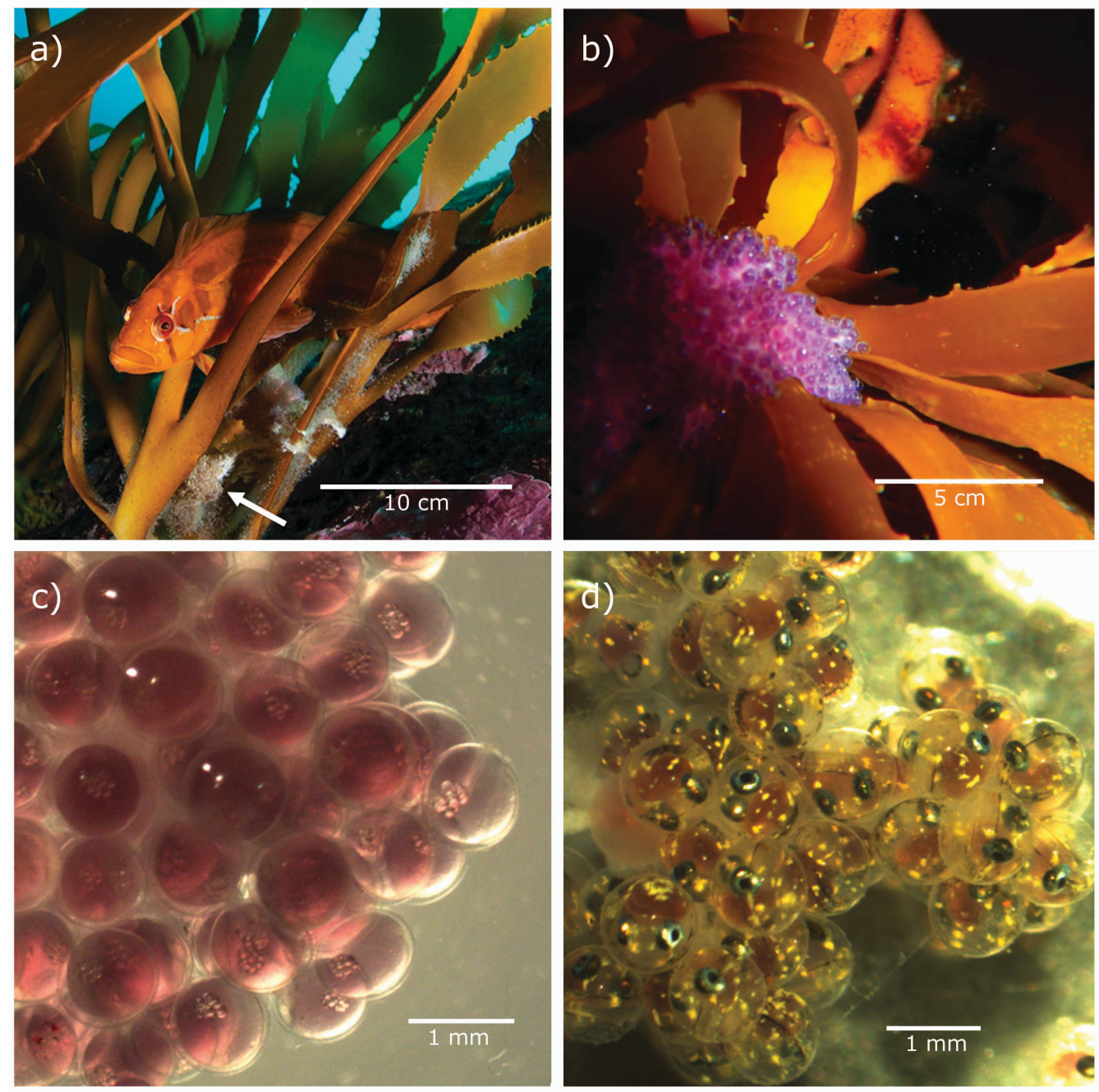

Figure 1. Macroscopic view of: a) $M$. viridis adult caring the egg clutch in the $L$. trabeculata frond, b) recently spawned egg clutch showing its characteristic purple color $\mathrm{c}$ ) the egg clutch at early development stage and d) at late development stage. Photograph author: a) Eduardo Sorensen, b) Javier Vera / Vista macroscópica de: a) adulto de $M$. viridis cuidando la postura de huevos en la fronda de $L$. trabeculata, b) postura de huevos recién desovados que muestra su característico color púrpura, c) huevos en la etapa de desarrollo temprano y d) en la etapa de desarrollo tardía. Autor de la fotografía: a) Eduardo Sorensen, b) Javier Vera 


\section{MATERIALS AND METHODS}

Multiple egg masses of $M$. viridis, hereinafter called clutches (Fig. 1), were found during austral autumn-winter months (April to July) of 2016 in shallow subtidal (0-7 m) kelp forests at three sites on the central Chilean coast: Punta de

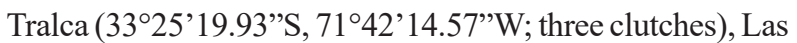

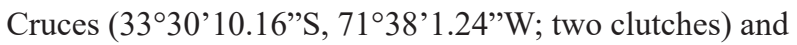

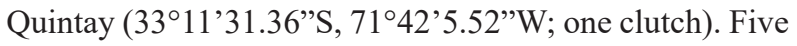
egg clutches were found attached to Lessonia trabeculata, and one from Las Cruces was attached to a collector (a PVC plastic mesh) fixed to L. trabeculata stipes. For each clutch, the presence, size (TL) and behavior of adults (Fig. 1a) were recorded and a sub-sample of eggs (about $10 \%$ of egg clutch) was collected. All samples were transported in individual $20 \mathrm{~L}$ plastic tanks with aerated seawater to the nearby laboratory of the Estación Costera de Investigaciones Marinas (ECIM) at Las Cruces. Once in the laboratory, the eggs from each clutch were maintained in individual $50 \mathrm{~L}$ containers with filtered $(0.45 \mu \mathrm{m})$ running seawater $\left(14-15^{\circ} \mathrm{C}\right)$ and constant aeration. In addition, an adult fish guarding the nest at Quintay was captured to determine sex via gonad analysis.

In order to describe embryonic development of $M$. viridis, eggs were monitored daily until hatching. Each day, ten randomly-chosen eggs per clutch were carefully removed with a pipette and photographed (stereomicroscope Olympus SZ61, camera Micro Imaging CMOS, resolution 5.0 MPixel). Afterward, sampled eggs were fixed with $4 \%$ formaldehyde for $24 \mathrm{~h}$ and further preserved in $95 \%$ ethanol. The development was categorized into stages according to characteristics such as oil droplet position, eye development, pigmentation patterns, and tail formation, following Kingsford (1985) and Stepien (1986). Embryonic development time was estimated within each egg clutch as the number of days to reach hatching from specific development stages. In two clutches, more than one stage was observed; in those cases, only the most advanced stages were considered. Finally, egg diameter was measured and volume (estimated as sphere volume with egg radius) was determined for five individuals per development stage per clutch through photo analysis using ImageJ software $1.49 \mathrm{v}$.

Once larvae hatched, 30-50 individuals from each clutch were maintained in $50 \mathrm{~mL}$ containers, with constant aeration and temperature $\left(14{ }^{\circ} \mathrm{C}\right)$ and seawater replacement twice per day. From these, 10 individuals were randomly selected each day and anesthetized with $0.1 \mathrm{~mL}$ of benzocaine (BZ®-20 Veterquímica S.A.), measured (total length, TL) and photographed along the left lateral side. Afterwards, the individuals were allowed to recover and returned to the experimental $50 \mathrm{~mL}$ containers.
Geometric morphometric analysis was used to evaluate body shape changes and was based on ten landmarks: 1) snout tip, 2) upper head margin, 3) projection of anus over the dorsal margin, 4) posterior tip of the notochord, 5) anus, 6) lower jaw angle 7) ventral margin of eye, 8) anterior margin of eye, 9) dorsal margin of eye, and 10) posterior margin of eye (Fig. S1, and see Miller \& Kendall 2009). A total of 91 pictures of larvae were selected to digitize landmarks with the software TpsDig2 (version 2.22, Rohlf 2006). To assess the relative amount of variation among individuals and potential measurement error, the digitalization of landmarks was repeated for the same 91 individuals and a Procrustes ANOVA was performed. To test for different body shapes, Principal Component Analysis (PCA) was used. Specifically, variation in larval body shape during the 7 days after hatching was evaluated and larvae were grouped into three categories according to post-hatching time A) $0-24 \mathrm{~h}(\mathrm{n}=28)$, B) $2-4$ days $(\mathrm{n}=33)$, C) $5-7$ days $(n=30)$. Finally, a multivariate regression analysis was performed to determine whether size could affect the body shape through development (allometry) using centroid size as an independent variable and Procrustes coordinates as dependent variables (regression score). All analyses were performed using the program MorphoJ (version 1.06d, Klingenberg 2011).

\section{RESULTS AND DISCUSSION}

At all sites, one egg clutch was found on a single individual of L. trabeculata. All clutches were attached by elastic filaments to the stipes of the kelp, just below the blade origin (Fig. 1a, b). All egg clutches were actively guarded by one large ( $>15 \mathrm{~cm}$ TL) M. viridis (Fig. 1a), except for one clutch at Punta de Tralca, where beside the large specimen, two smaller (10 cm TL) conspecifics were found closer to the egg clutch. Gonad analysis of the large adult collected revealed it to be a male. Although no other adults were analyzed, they showed a similar size (i.e., $>15 \mathrm{~cm} \mathrm{TL}$ ) and guarding behavior, so it was assumed that all guarding specimens were male. Guarding adults did not exhibit aggressive behavior towards the divers but remained close to the eggs.

Eggs were spherical with an average diameter of 1.04 $\mathrm{mm}( \pm 0.003 \mathrm{SD})$ and volume of $0.6 \mathrm{~mm}^{3}$ ( $\left.\pm 0.005 \mathrm{SD}\right)$. The eggs were either purple in color, during early embryonic development (Fig. 1c), turning to bright golden in late stages (Fig. 1d). 


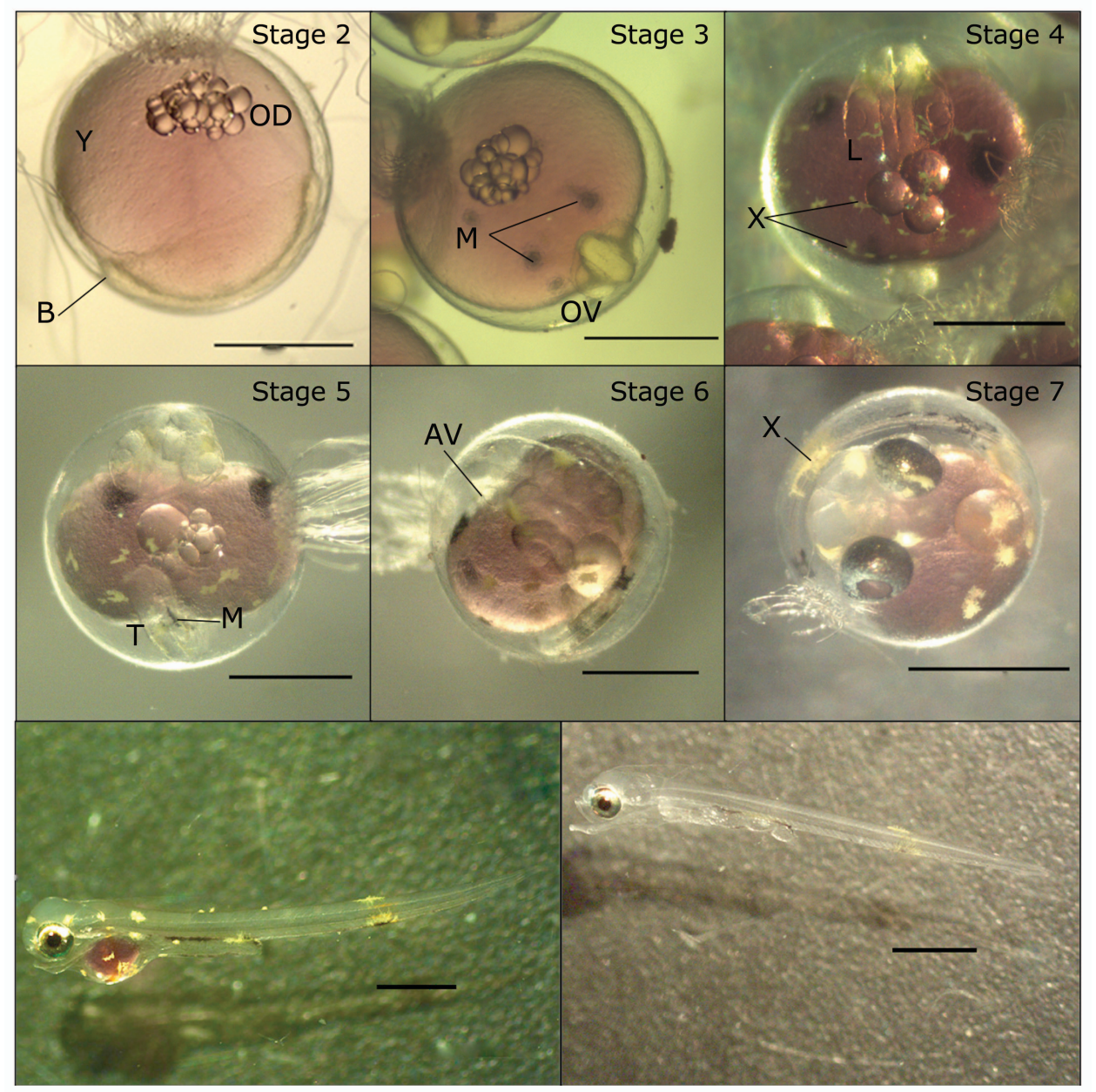

Figura 2. Embryonic developmental stages of $M$. viridis with representative photographs of each one. Pictures of larvae show first day post-hatching and the seventh day of hatching. Letters indicate principal structures of each stage (Y: yolk, B: blastodisc, OD: oil droplet, M: melanophores, OV: optic vesicle, X: xantophores, L: leucophores, T: tail, AV: auditory vesicle). Scales bars on eggs represent $0.5 \mathrm{~mm}$ and in larvae $1 \mathrm{~mm} /$ Etapas de desarrollo embrionario de $M$. viridis con fotografías representativas de cada uno. Imágenes de larvas muestran el primer día después de la eclosión y el séptimo día posterior a la eclosión. Escalas en huevos representan $0,5 \mathrm{~mm}$ y en larvas $1 \mathrm{~mm}$. Las letras indican las estructuras principales de cada etapa (Y: vitelo, B: blastodisco, OD: gota de aceite, M: melanóforos, OV: vesícula óptica, X: xantóforos, L: leucóforos, T: cola, AV: vesícula auditiva)

Based on structure development and pigmentation, eggs/embryos were grouped into 7 different stages (Fig. 2). As the earliest stage observed from field-collected eggs was neurula, all previous stages, including cleavage and gastrulation, were grouped together as $1^{\text {st }}$ stage. During $\sim 48 \mathrm{~h}$, the stage of neurula $\left(2^{\text {nd }}\right.$ stage) presented an $80 \%$ of the egg volume composed of yolk, of which a third corresponded to the blastodisc, and multiples oil droplets were present. The $3^{\text {rd }}$ stage was characterized by cephalization, optic vesicle development, with anterior and posterior regions identifiable by the end of day 4 . Four melanophores appeared and multiple oil droplets remained. After 6 days, a $4^{\text {th }}$ stage was indicated by head feature and full eyes, thickened tail, and reduced yolk exhibiting a "kidney" shape. Somites and xanthophores were visible at this stage. The $5^{\text {th }}$ stage ( $>8$ days) was defined by the appearance of a melanophore on the tail, the separation of tail from the yolk, and the presence of the auditory vesicle. The beginning of eye pigmentation, an increase in iridescence and movements characterized the $6^{\text {th }}$ stage which lasted up to 12 days. Lastly, at pre-hatching stage $\left(7^{\text {th }}\right.$ stage), eye pigmentation became bluish in color, xanthophores were dispersed around the body, the yolk was reduced by half and the embryo was in constant movement. This last stage persisted about 4 days until hatching. Although variable, most of the oil droplets coalesced into just one large droplet during the last two stages.

Size of newly hatched larvae, measured within $24 \mathrm{~h}$ after hatching, was on average $5.20( \pm 0.39 \mathrm{SD}) \mathrm{mm} \mathrm{TL}$, ranging from $4.04-5.98 \mathrm{~mm}$. Larvae hatched with fully pigmented eyes, a well-developed mouth, and active swimming abilities. The yolk sac was entirely consumed by the 5th day post-hatching. Most of the melanophores were branched and one in the ventral post-anal region overlapped with a xanthophore. Other branched xanthophore and melanophores were present in the gut, but xanthophores gradually disappeared during development and by the 7th day post-hatching only the melanophores in the tail and gut remained (Fig. 2). 
Results from Procrustes ANOVA estimate an error of $5.5 \%$ (Individual effect: $\mathrm{SS}=0.226, \mathrm{MS}=1.57 \times 10^{-4}, \mathrm{df}=$ $1440, \mathrm{~F}=18.09, P$-value $<0.0001$; Residual effect: $\mathrm{SS}=$ $\left.1.27 \times 10^{-2}, \mathrm{MS}=8.69 \times 10^{-6}, \mathrm{df}=1456\right)$. Ontogenetic allometry progressed on average at a rate of $10.6 \%$, where the permutation test against the null hypothesis of independence gave a $P$-value $=0.001$. Principal Component Analysis (PCA) described the primary sources of larval body shape variation defined by $\mathrm{PC} 1$ and $\mathrm{PC} 2$, which explained 52.3 and $16.0 \%$ of variation, respectively. Variation in PC1 explained the deformation across the dorso-ventral axis (Fig. S2). For PC2, shape variation was mainly in the head, specifically a displacement of the eye upward relative to the maxilla, which resulted in an elongated and pointed head (Fig. S2).

Regarding the characters of the newly hatched larvae, two-branched xanthophores and a melanophore present in the post-anal region confirm this as a useful taxonomic character (Zavala-Muñoz et al. 2016). Also, a welldeveloped mouth, vigorous swimming movements and yolk consumption suggest that $M$. viridis larvae could be able to feed on plankton early in their larval development. In fact, smaller sizes of $M$. viridis larvae have been reported with gut contents (Ochoa-Muñoz et al. 2013) and the main body shape changes the head region are directly related development of anatomical structures involved in prey localization (vision) and capture (as jaws) necessary for the transition from endogenous yolk consumption to exogenous prey feeding (Sanderson \& Kupferberg 1999, Yúfera \& Darias 2007).

Regarding the reproductive patterns of clinids, our results indicate some common features about the reproductive traits between $M$. viridis and Heterostichus rostratus (Myxodini), the North American giant kelpfish. First, incubation time and egg size seem to be similar in these two species, as $H$. rostratus eggs are $1.4 \mathrm{~mm}$ of diameter and develop slightly faster (12-17 days at 18 ${ }^{\circ} \mathrm{C}$; Stepien 1986). Also, structure development timing in the embryos of both species seems similar, ending with a hatching stage characterized by a yolk-sack larva with observable jaws, eye pigmentation and pectoral fins (Stepien 1986); where H. rostratus larvae hatch with a $6.2 \mathrm{~mm}$ TL. In this study, neither fertilization nor first embryo development stages (i.e., blastula and gastrula) were observed, but it is suggested they are likely similar to $H$. rostratus because of the similarity in environmental temperature, egg sizes and timing of events observed here. Finally, these two species spawn in a vegetal substratum without previous parental care modifications, however, $H$. rostratus select mainly turf algae rather than kelp (Coyer 1982).
Parental care is a common strategy in blennioids, where male size has been reported as a selected trait by females (Neat \& Lengkeek 2009). An interesting observation was the presence of smaller conspecifics near a male guarding the same egg clutch, and the occurrence of different stages of eggs within the egg clutch. It has been reported that when males are in charge of parental care, it is common that multiple females spawn in the same egg clutch (see Coleman \& Jones 2011). Our observations contrast that described for $H$. rostratus behavior, in which guarding males chase away all conspecifics and egg clutches are composed of eggs of similar developmental stage (Coyer 1982, Stepien 1986).

Finally, the choice of an appropriate spawning site is one of the fundamental processes affecting offspring success (Neat \& Lengkeek 2009, Hastings \& Petersen 2010). The consistent sighting of $M$. viridis egg postures in kelp fronds across sites separated by $>10 \mathrm{kms}$ suggest that this substrate represents a prime place for spawning in central Chile. Considering their ability to mimic kelp fronds, it makes sense that $M$. viridis spawning onto kelp could facilitate avoidance of predators, as in other species that camouflage their nest or themselves (Smith \& Wootton 1995). Parental care within the kelp forest may also be enhanced indirectly via food provisioning, as indeed the diet of Myxodes viridis is characterized by kelp fronds' epifauna, specifically small crustaceans such as peracarid amphipods and small decapods (Quijada \& Cáceres 2000, Thiel \& Hinojosa 2009, Winkler et al. 2017). Furthermore, L. trabeculata might contribute directly to egg development by providing a constant oxygen supply produced by kelp photosynthesis, and also reducing water flow of the shallow subtidal area (Trujillo et al. 2019).

The present study provides information of the interaction between $L$. trabeculata kelp and $M$. viridis (for other examples see: Garmendia 2016, Ruz et al. 2018), highlighting the importance of kelp for early life history of some reef fishes. Examples of use of this kelp species fronds as reproduction zones are not limited to this clinid fish, as other fish species are known to use kelp stipes to deposit their egg capsules, such as the redspotted catshark (Schroederichthys chilensis), skates (Sympterigia brevicaudata) (Trujillo et al. 2019) and also invertebrates such as squid (Doryteuthis gahi) (Carrasco \& Pérez-Matus 2016). Other examples extend to small peracarids crustaceans that use the kelps during their entire life history, such as the amphipod Peramphithoe femorata, which actively fold and "glue" fronds to build nests in both Macrocystis pyrifera and in L. trabeculata (Thiel \& Hinojosa 2009). As the egg clutches described here were found while surveying only subtidal kelp forest of $L$. trabeculata, it remains to be determined what other type of reproduction sites exist, and the relative importance of kelp as a spawning and rearing habitat. 


\section{ACKNOWLEDGEMENTS}

We greatly appreciate the help of Bryan Bularz for helping us in collecting and sampling egg clutches from the field. Dr. Robert Lamb and Arley Muth kindly provided helpful comments on earlier versions of this manuscript. Eduardo Sorensen and Javier Vera facilitated the photographs. Finally, we thank the editor and anonymous reviewers whose suggestions greatly improved the final manuscript. This study was principally funded by FONDECYT Regular 1151094 and NERC-CONICYT S011692 to APM, and EAW recognizes support from FONDECYT Regular 1181719.

Contributions: All the authors actively participated in the research and contributed substantially to the manuscript. VG, CR and APM found the eggs; RMC, VG and CR worked in the laboratory, and all authors actively participated in data processing, analyses, and writing the manuscript.

\section{LITERATURE CITED}

Bernal-Durán V \& MF Landaeta. 2017. Feeding variations and shape changes of a temperate reef clingfish during its early ontogeny. Scientia Marina 81: 205-215.

Carrasco SA \& A Pérez-Matus. 2016. Inshore spawning grounds of the squid Doryteuthis gahi suggest the consistent use of defoliated kelp Lessonia trabeculata in Central Chilean waters. Marine Biology Research 12(3): 323-328.

Coleman SW \& AG Jones. 2011. Patterns of multiple paternity and maternity in fishes. Biological Journal of the Linnean Society 103(4): 735-760.

Coyer JA. 1982. Observations on the reproductive behavior of the giant kelpfish, Heterostichus rostratus (Pisces: Clinidae). Copeia 1982(2): 344-350.

Frederich B, D Adriaens \& P Vandewalle. 2008. Ontogenetic shape changes in Pomacentridae (Teleostei, Perciformes) and their relationships with feeding strategies: A geometric morphometric approach. Biological Journal of the Linnean Society 95: 92-105.

Fuiman LA \& DM Higgs. 1997. Ontogeny, growth and the recruitment process. In: Chambers RC \& EA Trippel (eds). Early life history and recruitment in fish populations, pp. 225-249. Springer Netherlands, Dordrecht.

Garmendia V. 2016. Reclutamiento y selección de hábitat en peces de arrecifes templados, asociado a la modificación en los rasgos físicos estructurales de Lessonia trabeculata. Tesis de Biología Marina, Universidad de Valparaíso, Viña del Mar, 62 pp.

Gross MR. 2005. The evolution of parental care. The Quarterly Review of Biology 80(1): 37-45.

Hastings PA \& CW Petersen. 2010. Parental care, oviposition sites, and mating systems of blennioid fishes. In: Cole KS (ed). Reproduction and sexuality in marine fishes, pp. 91116. University of California Press, California.

Helfman GS, BB Collete, DE Facey \& BW Bowen. 2009. Fishes as social animals: Reproduction. In: Helfman G, BB Collette, DE Facey \& BW Bowen (eds). The diversity of fishes: Biology, evolution, and ecology, pp. 455-476. Wiley-Blackwell, Chichester.
Klingenberg CP. 2011. MorphoJ: an integrated software package for geometric morphometrics. Molecular Ecology Resources 11(2): 353-357.

Landaeta MF, V Bernal-Durán, MI Castillo, M DíazAstudillo, B Fernández-General \& $P$ Núñez-Acuña. 2019. Nearshore environmental conditions influence larval growth and shape changes for a temperate rocky reef fish. Hydrobiologia 839: 159-176.

Mansur L, G Plaza, MF Landaeta \& FP Ojeda. 2014. Planktonic duration in fourteen species of intertidal rocky fishes from the south-eastern Pacific Ocean. Marine and Freshwater Research 65(10): 901-909.

Miller BS \& AW Kendall. 2009. Early life history of marine fishes, 364 pp. Berkeley: University of California Press, London.

Muñoz AA \& FP Ojeda. 1998. Guild structure of carnivorous intertidal fishes of the Chilean coast: implications of ontogenetic dietary shifts. Oecologia 114(4): 563-573.

Muñoz-Cordovez R, L De La Maza, A Pérez-Matus \& SA Carrasco. 2019. Embryonic and larval traits of the temperate damselfish Chromis crusma reveal important similarities with other Pomacentridae throughout the family's thermal range. Journal of Fish Biology 95(2): 613-623.

Navarrete-Fernández T, MF Landaeta, CA Bustos \& A Pérez-Matus. 2014. Nest building and description of parental care behavior in a temperate reef fish, Chromis crusma (Pisces: Pomacentridae). Revista Chilena de Historia Natural 87: 30. <http://dx.doi.org/10.1186/ S40693-014-0030-2>

Navarro J \& G Pequeño. 1979. Peces litorales de los archipiélagos de Chiloé y los Chonos. Revista de Biología Marina 16(3): 255-309.

Neat F \& W Lengkeek. 2009. Sexual selection in blennies. In: Patzner RA, EJ Gonçalves, PA Hastings \& BG Kapoor (eds). The biology of blennies, pp. 249-278. Science Publisher, New Hampshire.

Ochoa-Muñoz MJ, CP Valenzuela, S Toledo, CA Bustos \& MF Landaeta. 2013. Feeding of a larval clinid fish in a microtidal estuary from southern Chile. Revista de Biología Marina y Oceanografía 48(1): 45-57.

Pérez-Matus A, LA Ferry-Graham, A Cea \& JA Vásquez. 2007. Community structure of temperate reef fishes in kelpdominated subtidal habitats of northern Chile. Marine and Freshwater Research 58(12): 1069-1085.

Quijada PA \& CW Cáceres. 2000. Patrones de abundancia, composición trófica y distribución espacial del ensamble de peces intermareales de la zona centro-sur de Chile. Revista Chilena de Historia Natural 73(4): 739-747.

Reyes P \& M Hüne. 2012. Peces del sur de Chile, 498 pp. Ocho Libros, Santiago.

Ruz CS, AF Muth, F Tala \& A Pérez-Matus. 2018. The herbivorous fish, Aplodactylus punctatus, as a potential facilitator of dispersal of kelp, Lessonia trabeculata, in Chile. Journal of Experimental Marine Biology and Ecology 500: 112-119.

Sanderson SL \& SJ Kupferberg. 1999. Development and evolution of aquatic larval feeding mechanisms. In: Hall BK \& MH Wake (eds). The origin and evolution of larval forms, pp. 301-377. Academic Press, San Diego. 
Smith C \& RJ Wootton. 1995. The costs of parental care in teleost fishes. Reviews in Fish Biology and Fisheries 5(1): 7-22.

Stepien CA. 1986. Life history and larval development of the giant kelpfish, Heterostichus rostratus Girard, 1854. Fishery Bulletin 84(4): 809-826.

Stepien CA. 1990. Population structure, diets and biogeographic relationships of a rocky intertidal fish assemblage in central Chile: high levels of herbivory in a temperate system. Bulletin of Marine Science 47: 598-612.

Stepien CA. 1992. Evolution and biogeography of the Clinidae (Teleostei: Blennioidei). Copeia 1992(2): 375-392.

Thiel M \& IA Hinojosa. 2009. Peracarida-anfípodos, isópodos, tanaidáceos \& cumáceos. In: Häussermann V \& G Försterra (eds). Fauna marina bentónica de la Patagonia chilena, pp. 671-738. Nature in Focus, Santiago.

Toro-Ibacache MV, G Manriquez-Soto \& I SuazoGaldames. 2010. Morfometría geométrica y el estudio de las formas biológicas: De la morfología descriptiva a la morfología cuantitativa. International Journal of Morphology 28: 977-990.
Trujillo JE, LM Pardo, L Vargas-Chacoff \& N Valdivia. 2019. Sharks in the forest: relationships between kelp physical-complexity attributes and egg deposition sites of the red-spotted catshark. Marine Ecology Progress Series 610: 125-135.

Yúfera M \& MJ Darias. 2007. The onset of exogenous feeding in marine fish larvae. Aquaculture 268(1/4): 53-63.

Winkler NS, A Pérez-Matus, ÁA Villena \& M Thiel. 2017. Seasonal variation in epifaunal communities associated with giant kelp (Macrocystis pyrifera) at an upwellingdominated site. Austral Ecology 42(2): 132-144.

Zavala-Muñoz F, ML Landaeta, V Bernal-Durán, GA Herrera \& DI Brown. 2016. Larval development and shape variation of the kelpfish Myxodes viridis (Teleostei: Clinidae). Scientia Marina 80(1): 39-49.

Received 24 June 2020 and accepted 25 September 2020

Associated editor: Mauricio Landaeta D. 


\section{SUPPLEMENTARY FIGURES}

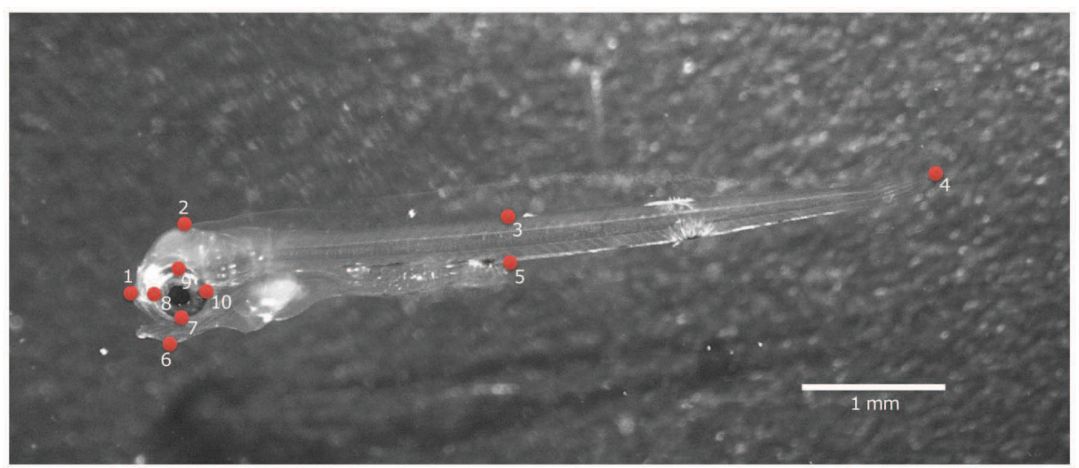

Figure S1. Location of landmarks digitized for the geometric morphometrics analysis of Myxodes viridis larvae / Posición de los landmarks digitalizados para el análisis de morfometría geométrica en larvas de Myxodes viridis

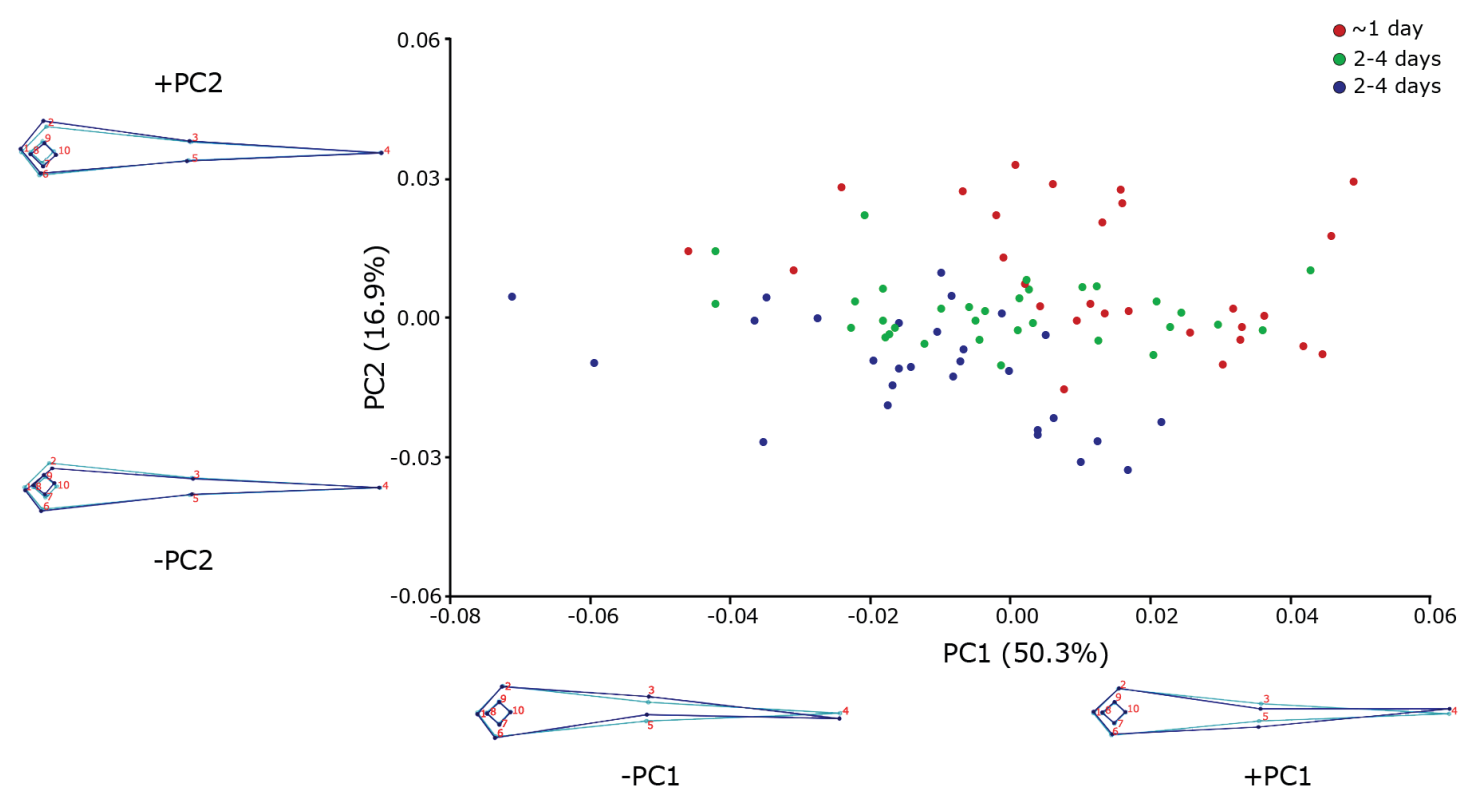

Figure S2. Principal Component Analysis (PCA) plot of variation in larval body shape. Colors represent to larval time of development in lab (red: recently hatched larvae $\sim 1$ day, green: larvae between 2 and 4 days, blue: larvae between 5 and 7 days). Wireframes indicate the extreme shape along both PC axes / Gráfico del Análisis de Componentes Principales (PCA) de la variación la forma del cuerpo de la larva. Colores indican el tiempo de desarrollo larval en laboratorio (rojo: larvas recién eclosionadas 1 día, verde: larvas entre 2 y 4 días, azul: larvas entre 5 a 7 días). Modelo representativo de las formas de la larva. Se muestran las formas extremas a lo largo del eje de los componentes 